\title{
Blended learning innovation of social media based active English during the COVID-19 pandemic
}

\author{
Ali Mustadi, Primary Education Department of Graduate School Universitas Negeri Yogyakarta, Indonesia, \\ ali_mustadi@uny.ac.id ORCID:0000-0002-7620-4582 \\ Fatika Chandra Annisa, Primary Teacher Education Department of Education Faculty Universitas Negeri \\ Yogyakarta, Indonesia, fatikachandraannisa@gmail.com \\ Adhe Putri Mursidi, Primary Teacher Education Department of Education Faculty Universitas Negeri \\ Yogyakarta, Indonesia, m.adheputri11@gmail.com
}

\begin{abstract}
This study aims to describe the implementation of blended learning innovation of social mediabased (sosmed-based) English teaching in improving students' active English skill during the Covid19 Pandemic. The innovation was made by implementing the Communicative Approach which integrated elearning platforms including Be-Smart, Zoom, and Google Classroom with social media (YouTube, Instagram, Facebook). The indicators of active English skill are: students' activeness, self-confidence, and creativity and innovation in producing and uploading the videos of English practice to the social media during English classes. This research used the qualitative approach with the case study type. The subjects were PTE students of classes 2A, B, C, and D, Faculty of Education, Yogyakarta State University in the academic year of 2019-2020. The subjects were one lecturer and eight students established by using the purposive sampling technique. This study was conducted from January to April 2020. The data were collected though observation, interviews, field notes, and documentation. The data analysis used the interactive analysis form Miles and Huberman. The result shows that the innovation of blended learning in sosmed-based active English class which used the Communicative Approach integrated e-learning platforms of Be-Smart, Zoom, and Google Classroom with social media (YouTube, Instagram, Facebook) could improve active English skill of the students in Covid19 pandemic. This can be seen from the students' activeness and self-confidence, creativity and innovation in producing and uploading the videos of English practice because they need a number of likes, views, and subscribers so it could naturally motivate them to do their best in order to improve their motivation and active English skill.
\end{abstract}

Keywords: Blended Learning, Social Media, Active English skill Received: 07.12.2020 Accepted: 24.01.2021

Published: 01.02.2021

\section{INTRODUCTION}

The competence in foreign languages, especially English, must surely be achieved by the Indonesian young generation. Along with the advancement of science and technology in this era, every individual is demanded to have good qualification and competence, particularly in communication. In this case, the mastery of the English language is highly required in order to master communication technology and to interact with other people (Ahmadi, 2018). Therefore, there must be an active mastery of English, both in writing and speaking.

The Department of Primary Teacher Education (PTE), Faculty of Education, Yogyakarta State University is obliged to produce teacher candidates who are qualified and professional. One of the ways is by equipping them with the active English competence, both in speaking and writing. The students are offered the English subject as the general subject they have to undertake so that they can improve their English competence well.

The participation level of the PTE Department students in the academic year of 2019/2020 in the English teaching-learning process very much depends on the role of the lecturer as the classroom manager. The teaching method used functions not only to transfer knowledge from the lecturer to students. However, how can the lecturer make the students self-confident in developing and practicing their English competence which they have got from the teaching-learning processes?

In the process of teaching the English subject, constraints often arise. Megawati (2016) mentions that the difficulties that inhibit students in using English is their inability to pronounce English words well. This inability can lower their self-confidence in using their oral English in everyday life. Viewed from the values of everyday practice done by the students, this inability shows that the ability to communicate in English is still low. In line with Megawati, Devi \& Rao (2018) also mention that the 
constraints faced by the students in learning English can be in the form of anxiety in expressing ideas, limited knowledge, first language interference, limited practice, and fear of making mistakes. Those constraints surely inhibit the objectives of English language teaching. The students are often inactive in expressing themselves using the English language. This is due to the English teaching which is conventional and focusing on sentence structures. Therefore the students are only taught about the correct and incorrect sentence structures and not about the real use of English in everyday life, so that they do not have the opportunity to communicate in English, neither in speaking nor in writing.

Based on the above situation, there needs to be developed a varied and appropriate teaching method. If a monotonous and conventional method is still used in its teaching, the English subject will be a specter which haunts the students. An alternative solution to the problem is by applying a teaching method which is appropriate and enables the students to improve their self-confidence in using the English language actively, that is by using the communicative competence method. This method leads to language function, which is a means of communication involving the students to master the four language skills (Tavil, 2010). The innovation in applying this method is by utilizing blended learning to support teaching in the digital era nowadays.

Blended learning is a teaching-learning approach which combines two teaching methods: placebased classroom method and online interaction method (Kocoglu, Ozek, \& Kesli, 2011), (Ozmen, Tepe, \& Tuzun, 2018). As a mixed teaching method, blended learning has the strength in the ease in accessing resources everywhere at any time through the Internet. Therefore, blended learning is very useful in supporting the teaching of English to the PTE Department students.

In blended learning method, various platforms are used to facilitate the English teaching process, one of which is the platform owned by Yogyakarta State University (YSU) called Be-Smart, which is an electronic-based interactive teaching media intended to be used by the students and lecturers of YSU. BeSmart makes it possible for all materials, quizzes, and English assignments to be accessed directly and to be used as the replacement of classroom-based lectures, which makes lecture relaxing and flexible.

Another platform used to support the blended learning activities of the PTE students is YouTube, which is able to support the effective process of the teaching of English to students. It can be used as a medium of communication and teaching which fulfills students' needs, enhances interests, and helps digital generation learning style nowadays (Burke, Snyder, \& RC, 2009), (Fleck, Beckman, Sterns, \& Hussey, 2014). By uploading the video of English materials into YouTube, the students are expected to be more self-confident in using active English orally in public. The uploaded materials have to be suitable with the teaching load to achieve, so that learning is experienced maximally and enjoyably. Besides, by uploading videos into YouTube, the students can sharpen their innovation and creativity (Moghavvemi, Sulaiman, Jaafar, \& Kasem, 2018). The uploaded videos can be edited in such a way that it results in a more interesting and informative content. Through this interesting content, the level of students' participation in teaching-learning English processes improves (Hamad, Metwally, \& Alfaruque, 2019).

The uploaded videos have to be distributed to their classmates and the surrounding people through the social media of WhatsApp and Instagram so that they will show their 'likes' and being subscribers in the student YouTube. By uploading English videos, the students certainly experience a holistic learning process, such as learning to make English sentences accurately according to language norms (grammar), speaking in front of a camera with appropriate pronunciation and body gesture, up to learning how to edit videos as interestingly as possible in order to attract the viewers, and to get 'likes' and subscribers as many as possible. The students are also very responsible for their videos, because the videos can be accessed by anyone, anytime, and anywhere. This learning process can surely improve their competence, not only in communicating actively in English but also in expressing ideas and socializing well. Beside the two platforms above, blended learning processes also use Zoom for online interaction, and Google Classroom as an online discussion forum as well as for submitting assignments. With many platforms supporting blended learning activities, learning can be done maximally and holistically.

This study aims to explore the teaching of the English subject applying the Communicative Approach integrating blended learning (classroom-based and online through: YouTube, Be-Smart, Zoom, and Google Classroom) which can improve students' learning achievement, creativity, innovation, and self-confidence in English speaking by uploading learning material videos in YouTube.

\section{Communicative Approach}

Jabeen (2014) states that the Communicative Approach is an approach which is theoretically most effective in the English teaching in early 1970's. The conceptual stress of the Communicative Approach is not only in the meaning functions but also the social function. Learning English is not focused on the language form but on the understanding. The Communicative Approach plays a crucial role in the teaching and learning of languages (Akkas \& Coker, 2016). It teaches students how to communicate 
meaningfully in the classroom, so that it can help students develop their communication skill (Abrejo, Sartaj, \& Memon, 2019; Yang, 2014). This opinion is in line with that of Lukyanova, Daneykin, \& Daneikina (2015) who state that the use of the Communicative Approach in universities can improve the students' communication quality and the alumnus quality to be professional. The students can independently improve their communication ability when this approach is applied. In this study, the goal of applying this approach is that the students are able to express their ideas actively in the oral form in front of the lecturer and their peers.

\section{Blended Learnıng}

Blended learning is an alternative teaching method which can be applied in English teaching. Grgurović (2014) describes blended learning as classroom teaching which combines classroom-based activities and online activities which are prepared pedagogically. As a mixed teaching method, blended learning has the strength in the ease in accessing resources everywhere at any time through the Internet. Besides, communication between the lecturer and students can run well regardless of the time and place. According to Inal \& Korkmaz (2019), Rahmawati (2019), Shebansky (2018), and Siew-Eng \& Muuk (2015) the reason for applying blended learning is that it can improve students' learning achievement, support collaboration, improve access to learning materials, develop the independent learning skill, and produce a solutive individual. The teaching of English using the Communicative Approach integrating blended learning provides different learning experience to students, because they are not solely taught through the conventional teaching method which focuses only on one learning resource through face-toface interaction. Therefore, the application of the blended learning method becomes one of the alternatives in the teaching of English to students because it has the strength in supporting the development of the English competence of the students, particularly those of the Department of Primary Teacher Education, Yogyakarta State University.

\section{Socıal Media as Learnıng Media}

The application of blended learning needs various supporting platforms in the process of online teaching. One of the platforms used beside a website can be in the form of social media such as YouTube, Facebook, WhatsApp, and Instagram. Erarslan (2019) states that social media is an effective media in supporting the teaching which is open, interactive, and social environment-friendly. It gives a positive impact on the students in their involvement in teaching and in improving their language skill (Kitchakarn, 2016; Miller, Morgan, \& Koronkiewicz, 2019; Woods, Gomez, \& Arnold, 2019). Li (2017) also mentions that social media can teach students to be independent in exploring learning materials. In relation to English teaching, the use of social media can give learning experience directly not strictly textbook-oriented, so that the students show their English-speaking skill maximally through social media as the platform like what has been applied in the teaching of English to PTE students in improving their active English skill.

\section{METHODS}

\section{Research Design}

This research is a qualitative study of the case study type. The researcher is the main instrument, so that he involved actively in observing, interviewing, and recording all phenomena occurring during the study. The relevance of the research approach is that qualitative research is the research which portraits directly the academic background or the context of an entity. In this case, the context is the English teaching and learning activities using the Communicative Approach and blended learning innovation based on social media with the aim of improving the active English skill of the students of the Department of Primary Teacher Education, Yogyakarta State University (PTE YSU).

This study was conducted at the PTE Department, YSU, from January 27 to April 30, 2020, at classes A, B, C, and D of undergraduate students of 2019, involving 179 students with a sample of 42 students established using the purposive sampling technique.

\section{Data Collection}

The research data were collected through observation, interviews, field notes, and documents. The observation is participatory as well as passive observation. Interviews were conducted to students by distributing a questionnaire, aiming at obtaining the information on the students' understanding of the English teaching applying the Communicative Approach and blended learning method, its application in the English lecture, its effect on their learning achievement, and the inhibiting factors in the application of the Communicative Approach and blended learning method in English teaching. Documentation was 
conducted to students' work and it aimed to obtain the information that completed the data obtained through observation and interviews.

\section{Data Analysis}

The data obtained are the results of the observation, interviews, field notes, and documentation. The data analysis was conducted not only after all the data were collected, but also since the beginning of the data collection, and it was done intensively after the field work. This could avoid data piling up that caused data saturation and difficulty in data processing.

In this case, the researcher saved the hand-written data in computer files. The process of data analysis followed the steps of collecting data, data condensation, and drawing conclusion. All of the data were read, learned, and reviewed and afterward data reduction was done by making abstraction. Abstraction is an effort to summarize the core, process, and statements which need to be kept so as to make them be kept inside.

The next step was making information units, which were found in field notes, interview notes, observation sheets, and documents. For example, in a field note the researcher wrote that the students followed several steps to prepare until they uploaded videos in YouTube and then submitted the assignments in Be-Smart. This can be considered as one information unit. One by one, the information units were classified into one category, i.e. lecturer role category.

\section{RESULTS}

\section{Findings}

The subjects of this research are the PTE Department students who were undertaking the general subject of English in the even semester of 2019/2020. The criteria for the subject selection were the English competence and innovation competence in making the English material content in social media.

The following is the steps of the English teaching to Classes A, B, C, and D in the Primary Teacher Education Program.

The planning of the English teaching was done by making lesson plans, student worksheet, assessment format, evaluation materials, and observation sheet. All of the teaching kits were made prior to the teaching in the classroom. One week before teaching in the classroom, the lecturer asked the students to study the materials and to do individual assignment in the form of videos about the materials to be studied in the following week. The materials were accessed in Be-Smart. The students accessed and learned the materials individually or in groups in accordance with the lecturer's suggestion.

\section{CONCLUSION}

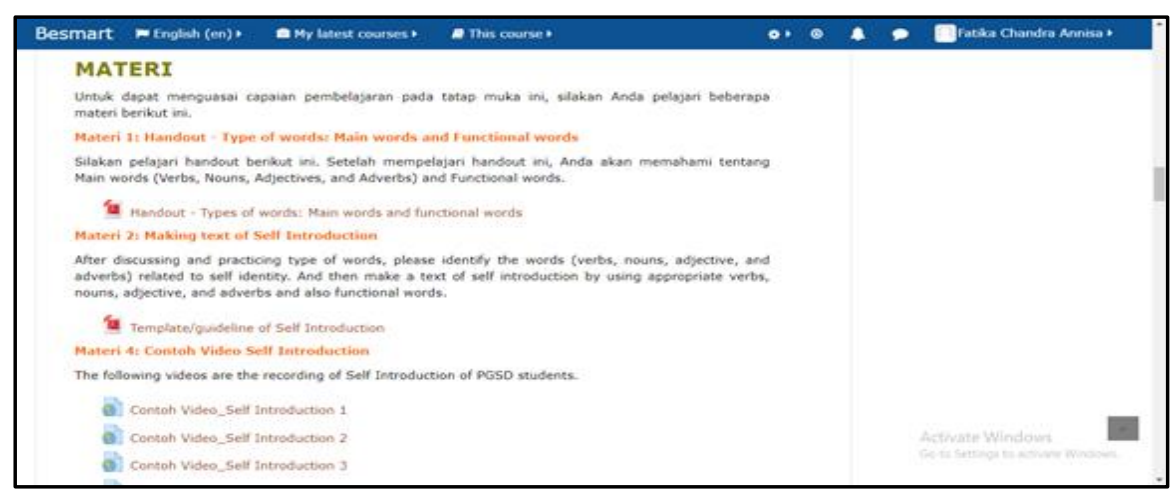

Figure 1. Screenshot of english be-smart (hi-2018) of the material "self introduction"

After accessing the materials in Be-Smart, the students looked at the instruction on the assignment in Be-Smart. The assignment was in the form of video related to the materials they had learned. They might ask questions and gave responses related to the teaching and assignment in the forum section of Be-Smart. In addition to being done at Be-Smart, the question-and-answer activity and giving responses could also be done using the Zoom or Google Classroom application. This depended on the direction from the lecturer. 
Having finished asking-answering questions and giving responses, the students did assignments in the form of videos in accordance with the materials they had learned in Be-Smart. The video shooting could be done anywhere and anytime in line with the context of the video being made.

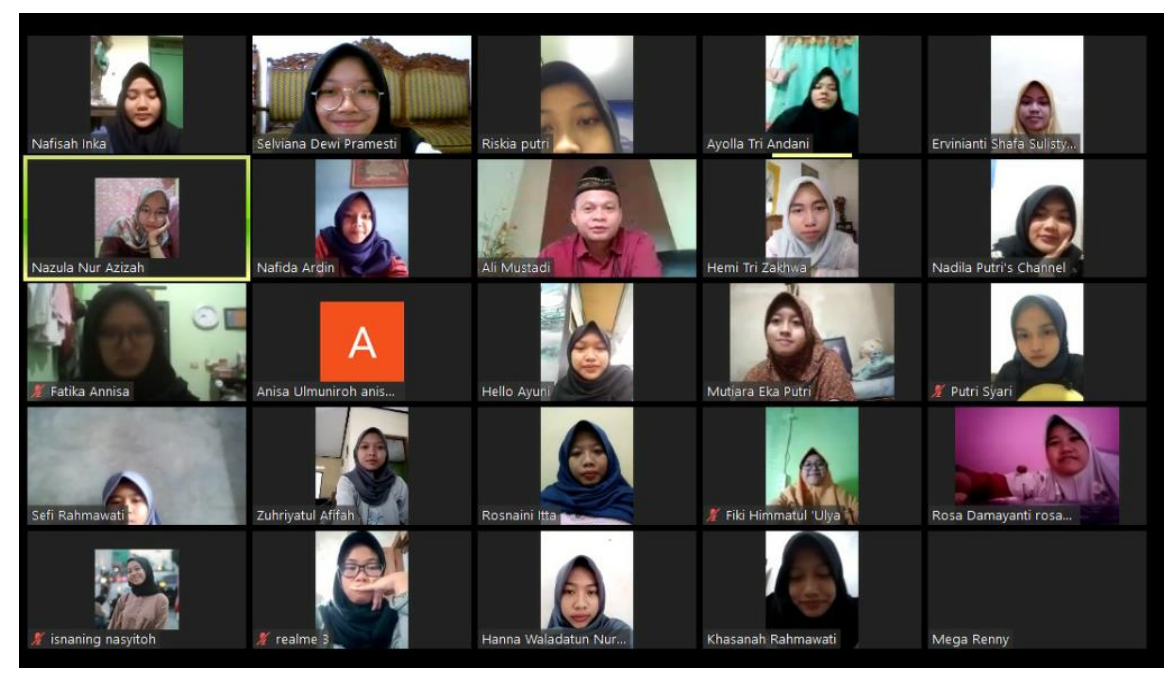

Figure 2. Screenshot of lecturer and students of class $C$ doing teaching-learning activities via zoom

Furthermore, the video that had been made could be edited in such a way that its content was interesting and educative. Then, it had to be uploaded to each student's channel in YouTube, which could be accessed by anyone at any time, and got likes and subscribers. Likes and subscribers are part of the assessment by the lecturer; the more the people who gave likes and became subscribers, the higher the score of the student who had uploaded the video.

The Link video that had been uploaded to YouTube had to be recorded and filed in individual assignment in Be-Smart. This was aimed at facilitating the lecturer to grade assignments and watch videos which had been made by the students. During classroom activities, the students were asked to take turn to present the videos they had made in front of the class.

Through discussion and question-and-answer activities, the lecturer explained again how to develop the materials the students had learned. Together with the students, the lecturer made the summary of the materials they had learned. He did the evaluation and self-reflection to analyze the success of the teaching and learning applying the Communicative Approach integrated with the blended learning method.

The following are the seven video tasks uploaded by the students to each Youtube Channel whose links had to be uploaded to Be-Smart and students' social media, i.e in Instagram and Facebook to get the number of likes, views, and subscribes within one semester:

1. Spelling Alphabet and Pronouncing Three Syllable Words (https://youtu.be/cjctQxpMKvE)

2. Self-Introduction (https://youtu.be/pM08mQACSkY)

3. Describing Thing (https://youtu.be/qdGZim8v2ck)

4. Retelling Story (Goldilocks and the Three Bears) (https://youtu.be/403I8PZQC1E)

5. Teaching Practice Kelas Rendah (https://youtu.be/xZeZ1ZUVq6s)

6. Teaching Practice Kelas Tinggi (https://youtu.be/n4irZoiyWjI)

7. Singing and Dancing (https://youtu.be/3MsM3iXA8ec)

As a result, the students were motivated naturally to perform their best, and this is the core of this active English teaching innovation. 


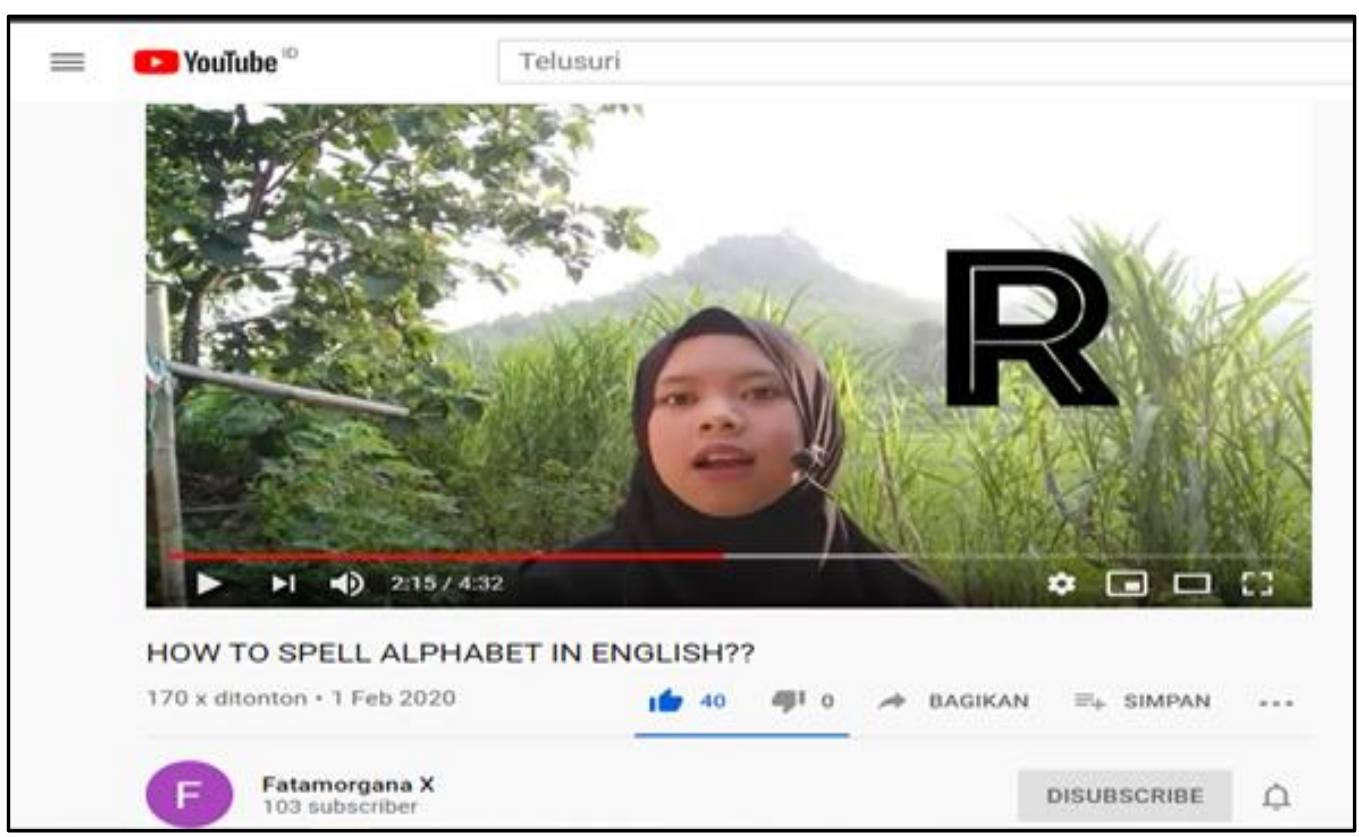

Figure 3. Screenshot of a video task uploade to youtube (https://youtu.be/cjctQxpMKvE)

\section{Implementation Results Data}

Table 1. Number of views, likes, and subscribers of video and YouTubechannel of PTE Classes A-D 2019 students

\begin{tabular}{|c|c|c|c|c|c|c|c|c|c|c|c|c|c|}
\hline \multirow{3}{*}{ No } & \multirow{3}{*}{ Video Task } & \multicolumn{12}{|l|}{ Kelas } \\
\hline & & \multicolumn{3}{|l|}{$2 \mathbf{A}$} & \multicolumn{3}{|l|}{ 2B } & \multicolumn{3}{|l|}{$2 \mathrm{C}$} & \multicolumn{3}{|l|}{ 2D } \\
\hline & & $\mathbf{V}$ & $\mathbf{L}$ & $\mathbf{S}$ & $\mathbf{V}$ & $\mathbf{L}$ & $\mathbf{S}$ & $\mathbf{V}$ & $\mathbf{L}$ & $\mathbf{S}$ & $\mathbf{V}$ & $\mathbf{L}$ & $\mathbf{S}$ \\
\hline 1 & $\begin{array}{l}\text { Spelling Alphabets } \\
\text { and Pronouncing } \\
\text { Three Syllable Words }\end{array}$ & $\begin{array}{l}1019 \\
7\end{array}$ & $\begin{array}{l}339 \\
4\end{array}$ & \multirow{7}{*}{$\begin{array}{l}342 \\
3\end{array}$} & $\begin{array}{l}883 \\
5\end{array}$ & $\begin{array}{l}307 \\
0\end{array}$ & \multirow{7}{*}{$\begin{array}{l}355 \\
4\end{array}$} & $\begin{array}{l}655 \\
5\end{array}$ & $\begin{array}{l}217 \\
6\end{array}$ & \multirow{7}{*}{$\begin{array}{l}247 \\
6\end{array}$} & $\begin{array}{l}914 \\
0\end{array}$ & $\begin{array}{l}287 \\
7\end{array}$ & \multirow{7}{*}{$\begin{array}{l}272 \\
8\end{array}$} \\
\hline 2 & Self-Introduction & 3621 & $\begin{array}{l}127 \\
5\end{array}$ & & $\begin{array}{l}318 \\
3\end{array}$ & $\begin{array}{l}122 \\
9\end{array}$ & & $\begin{array}{l}319 \\
1\end{array}$ & $\begin{array}{l}103 \\
1\end{array}$ & & $\begin{array}{l}430 \\
5\end{array}$ & $\begin{array}{l}107 \\
5\end{array}$ & \\
\hline 3 & Description Text 1 & 2903 & $\begin{array}{l}108 \\
6 \\
\end{array}$ & & $\begin{array}{l}301 \\
0 \\
\end{array}$ & $\begin{array}{l}117 \\
0 \\
\end{array}$ & & $\begin{array}{l}292 \\
4 \\
\end{array}$ & 690 & & $\begin{array}{l}282 \\
6 \\
\end{array}$ & 830 & \\
\hline 4 & Description Text 2 & 1566 & 626 & & $\begin{array}{l}249 \\
6\end{array}$ & $\begin{array}{l}101 \\
5\end{array}$ & & $\begin{array}{l}152 \\
6\end{array}$ & 439 & & $\begin{array}{l}224 \\
5\end{array}$ & 652 & \\
\hline 5 & Retelling Story & 1582 & 589 & & $\begin{array}{l}249 \\
0\end{array}$ & 995 & & $\begin{array}{l}176 \\
8\end{array}$ & 434 & & $\begin{array}{l}217 \\
8\end{array}$ & 573 & \\
\hline 6 & Singing and Dancing & 1701 & 573 & & $\begin{array}{l}265 \\
8 \\
\end{array}$ & 988 & & $\begin{array}{l}156 \\
1 \\
\end{array}$ & 467 & & $\begin{array}{l}126 \\
4\end{array}$ & 246 & \\
\hline 7 & $\begin{array}{l}\text { English for } \\
\text { Instruction: } \\
\text { Teaching Practice }\end{array}$ & 2291 & 832 & & $\begin{array}{l}434 \\
2\end{array}$ & $\begin{array}{l}182 \\
0\end{array}$ & & $\begin{array}{l}168 \\
0\end{array}$ & 490 & & $\begin{array}{l}248 \\
3\end{array}$ & 562 & \\
\hline
\end{tabular}

NB: V: viewers, L: likes, S: subscribers.

Table 1 above shows that the seven video tasks, consisting of "Spelling Alphabets and Pronouncing Three Syllable Words, Self-Introduction, Description Text 1, Description Text 2, Retelling Story, Singing and Dancing, and English for Instruction: Teaching Practice" have different numbers of subscribers. The classes that get the number of subscribers from the highest to the lowest are Classes 2B, 2A, 2D, and 2C. 
Table 2. Result of assessment of english assignments of pte classes a, b, c, and d semester 2 students of 2019

\begin{tabular}{|l|l|l|l|ll|}
\hline Score Range & Category & Frequency & Percentage & Class Achievement \\
\hline $86-100$ & Excellent & 44 & 24.58 & & \\
$71-85$ & Good & 105 & 58.65 & & \\
$56-70$ & Fair & 18 & 10.05 & Average score 78.167 \\
$41-55$ & Poor & 12 & 6.70 & (Good category) \\
$26-40$ & Fail & 00 & 00 & & \\
\cline { 1 - 1 } Total & 179 & 100 & & \\
\hline
\end{tabular}

Table 2 above shows that 44 students (24.58\%) are in the score range of 86-100 or in a very good category. As many as 105 students (58.65\%) are in the score range of 71-85 or in a good category. The number of the students who are in the score range of 56-70 or in the fair category is 18 students $(10.05 \%)$. While the number of the students who are in the score range of 41-55 or in a poor category is 12 students $(6.70 \%)$.

The result of the task assessment conducted classically as shown in the table above is the combination of four indicators of communicative competence and four indicators of English skills used in the assessment. The score of each indicator can be seen in Table 3 below.

Table 3. Results of each indicator of Communicative Competence

\begin{tabular}{|c|c|c|c|c|c|c|c|}
\hline No & Assessment Indicator & $\begin{array}{l}\text { Fail } \\
(\%)\end{array}$ & $\begin{array}{l}\text { Poor } \\
(\%)\end{array}$ & $\begin{array}{l}\text { Fair } \\
(\%)\end{array}$ & $\begin{array}{l}\text { Good } \\
\text { (\%) }\end{array}$ & $\begin{array}{l}\text { Excellent } \\
\text { (\%) }\end{array}$ & Average \\
\hline 1. & $\begin{array}{l}\text { Grammatical Competence } \\
\text { (competence related to } \\
\text { grammar, vocabulary, etc) }\end{array}$ & 00 & 17.87 & 18.99 & 51.95 & 11.17 & $\begin{array}{l}71.46 \\
\text { (Fair) }\end{array}$ \\
\hline 2. & $\begin{array}{l}\text { Discourse Competence } \\
\text { (competence } \\
\text { making/producing } \\
\text { different texts, orally and } \\
\text { in writing according to the } \\
\text { assignments given) }\end{array}$ & 00 & 5.02 & 9.49 & 65.92 & 19.55 & $\begin{array}{l}78.00 \\
\text { (Good) }\end{array}$ \\
\hline 3. & $\begin{array}{l}\text { Strategic Competence } \\
\text { (creativity competence in } \\
\text { making English practice } \\
\text { assignments) }\end{array}$ & 00 & 2.79 & 11.17 & 55.86 & 30.16 & $\begin{array}{l}80.01 \\
\text { (Good) }\end{array}$ \\
\hline 4. & $\begin{array}{l}\text { Sociolinguistic Competence } \\
\text { (competence in managing } \\
\text { practice assignments in } \\
\text { social media so the } \\
\text { number of users who } \\
\text { view, like, and subscribe } \\
\text { improves) }\end{array}$ & 00 & 5.58 & 7.26 & 64.24 & 22.90 & $\begin{array}{l}78.67 \\
\text { (Good) }\end{array}$ \\
\hline
\end{tabular}

The result of the assignments in terms of the aspect of communicative competence shows that for the indicator of Grammatical Competence (the competence related to grammar, vocabulary, etc) 93 students (51.95\%) are in the score range of 71 - 85 or in a good category; 34 students (18.99\%) are in the score range of 56 - 70 or in a fair category; 32 students (17.87\%) are still in the score range of 41 - 55 or in a poor category. All of this might be due to the fact that there were a lot of grammar materials the students had to learn and it took time and habituation, resulting in that so many sentences the students made were not in accordance with grammatical rules.

The result of the assignments in terms of the aspect of communicative competence shows that for the indicator of Discourse Competence (the competence in making/producing different kinds of texts, orally and in writing in accordance with the assignments given) 35 students (19.55\%) are in the score range of 86-100 or in a very good category; 118 students (65.92\%) are in the score range of 71-85 or in a 
good category; 17 students (9.49\%) are in the score range of 56-70 or in a fair category; nine students $(5.02 \%)$ are in the score range of $41-55$ or in a poor category.

The result of the assignments in terms of the aspect of communicative competence shows that for the indicator of Strategic Competence in general the students were good as shown by the fact that 54 students (30.16\%) are in the score range of $86-100$ or in a very good category; 100 students $(55.86 \%)$ are in the score range of 71-85 or in a good category; 100 students $(55.86 \%)$ are in the score range of 5670 or in a fair category. Five students $(2.79 \%)$ are in the score range of $41-55$ or in a poor category because the work tended to be monotonous, not showing creativity.

The result of the assignments in terms of the aspect of communicative competence shows that for the indicator of Sociolinguistic Competence, 41 students (22.90\%) are in the score range of 86-100 or in a very good category; 115 students (64.24\%) are in the score range of 71-85 or in a good category; 13 students $(7.26 \%)$ are in the score range of 56-70 or in a fair category. As many as 10 students (5.58\%) are in the score range of 41-55 or in a poor category because they did not show any efforts to good content in social media which could increase the number of views, likes, and subscribers.

Table 4. English skill of classes A, B, C, and D of semester 2 students 2019

\begin{tabular}{|l|l|l|l|l|l|l|l|}
\hline $\begin{array}{l}\text { No } \\
\cdot\end{array}$ & $\begin{array}{l}\text { English } \\
\text { Skill } \\
\text { Indicators }\end{array}$ & $\begin{array}{l}\text { Fail } \\
\mathbf{( \% )}\end{array}$ & $\begin{array}{l}\text { Poor } \\
\mathbf{( \% )}\end{array}$ & $\begin{array}{l}\text { Fair } \\
\mathbf{( \% )}\end{array}$ & $\begin{array}{l}\text { Good } \\
\mathbf{( \% )}\end{array}$ & $\begin{array}{l}\text { Excellent } \\
(\mathbf{\%})\end{array}$ & Average \\
\hline 1 & Listening & 00 & 9.49 & 12.84 & 55.86 & 21.78 & $\begin{array}{l}76.491 \\
\text { (Good) }\end{array}$ \\
\hline 2 & Speaking & 00 & 9.49 & 16.20 & 55.30 & 18.99 & $\begin{array}{l}75.569 \\
\text { (Good) }\end{array}$ \\
\hline 3 & Reading & 00 & 5.02 & 8,37 & 60.33 & 26.25 & $\begin{array}{l}79.173 \\
\text { (Good) }\end{array}$ \\
\hline 4 & Writing & 00 & 10.05 & 9.49 & 56.42 & 22.90 & $\begin{array}{l}76.826 \\
\text { (Good) }\end{array}$ \\
\hline
\end{tabular}

The result of the English skill test in the aspect of listening shows that 17 students (9.49\%) are still in the score range of 41-55 or in a poor category, 23 students (12.84\%) are in the score range of 56-70 or in a fair category, 100 students (55.86\%) are in the score range of 71-85 or in a good category, and 39 students $(21.78 \%)$ are in the score range of $86-100$ or in a very good category.

The result of the test in the aspect of speaking shows that 17 students $(9.49 \%)$ are still in the score range of 41-55 or in a poor category, while 29 students (16.20\%) are in the score range of 56-70 or in fair category, 99 students $(55.30 \%)$ are in the score range of 71-85 or in a good category, and 34 students (18.99\%) are in the score range of 86-100 or in a very good category.

The result of the test in the aspect of reading shows that nine students (5.02\%) are still in the score range of 41-55 or in a poor category, while 15 students (8.37\%) are in the score range of 56-70 or in a fair category, 108 students (60.33\%) are in the score range of 71-85 or in a good category, and 47 students $(26.25 \%)$ are in the score range of 86-100 or in a very good category.

The result of the test in the aspect of writing shows that 18 students $(10.05 \%)$ are still in the score range of 41-55 or in a poor category, while 19 students (9.49\%) are in the score range of 56-70 or in fair category, 101 students (56.42\%) are in the score range of 71-85 or in a good category, and 41 students $(22.90 \%)$ are in the score range of $86-100$ or in a very good category.

\section{Interview Result Data}

The result of the interviews conducted by the researcher shows that the teaching and learning activities implemented is very useful for improving the students' active English competence. This is shown by the students' responses below.

"During the teaching applying varied blended learning method, I feel that my English ability improves. By making English video, I feel more self-confident in front of the camera to give useful information to the viewers of my channel." (Interview 1: Ir/A/tgl).

The above response shows the teaching of the English subject applying the Communicative Approach using a varied blended learning method could improve the student' English competence. They felt more self-confident because they felt they were responsible for giving information to the viewers of their channel.

"In the making of English videos, I got the benefit in the form of the increase in vocabulary mastery which surely helps me in oral communication." (Interview 1: $\mathrm{Ag} / \mathrm{B} / \mathrm{tgl}$ ). 
The above response shows that the use of the Communicative Approach using the blended learning method increased the vocabulary mastery of the students. Their vocabulary mastery made communication easier for them, especially oral communication.

"I think the benefit I really get in relation to the English teaching and learning so far is that I understand more English, I know how to teach English to my students later, and I know the importance of learning English." (Interview 1: Al/C/tgl).

The above response shows the students also understood more about English teaching and the importance of learning English.

"I think, the benefit of this blended learning is that I can improve my English pronunciation and how to make effective sentences. Therefore it improves my English competence and my selfconfidence in English speaking." (Interview 1: In/D/tgl).

The above response shows that the implementation of the English lecture improved the students' English pronunciation and that they were better at making effective English sentences. Therefore, they felt more self-confident in communicating in English.

Based on the result of the interview with the representative of each class under study, it can be concluded that in general the implementation of the English subject applying the Communicative Approach using the blended learning method gives a positive impact on the students.

\section{DISCUSSION AND CONCLUSIONS}

In this study, the teaching of the English subject applying the blended learning method was in two different teaching processes: synchronous and asynchronous processes. The synchronous teaching (faceto-face) was conducted in the classroom when the lecturer and students met directly in person without any medium. The methods used in the synchronous teaching could be in the form of lecture, discussion, and question and answer. The synchronous teaching trained the students to develop their direct communication competence by expressing themselves during the teaching-learning processes (Tabak \& Rampal, 2014). Besides, the students could practice to socialize and communicate directly in English. They also had the opportunity to present the work they had prepared in front of the class. During the synchronous teaching the lecturer had the opportunity to measure his students' competence, such as listening comprehension. He administered an oral test in the classroom by playing audio materials through a loud speaker. Besides, the competence which could be measured in the synchronous teaching was writing comprehension. The lecturer played a video containing a short story, and then the students were asked to rewrite the story in their own words. The measurement of this competence is surely more effective during the synchronous teaching because the students are totally supervised by the lecturer in order that they try their best without cheating (Ramadhan, Chaeruman, \& Kustandi, 2018).

Another kind of interaction in blended learning in the English subject is asynchronous (long distant). The asynchronous teaching can use several online platforms to improve teaching efficiency and students' learning achievement (Sophocleous \& Loizides, 2016). The online platforms that could be used include Be-Smart, YouTube, and Zoom. In the asynchronous teaching, the students could develop their communication ability and express themselves in the written form. As one of the platforms that can be used in the asynchronous teaching, Be-Smart provides the room containing the materials which can be accessed by all students. This platform also provides a special column for the students to submit their assignments and to discuss in a forum. In the English teaching in this study, the students were asked to access materials, submit assignments, and discus in a forum in this platform weekly. Different materials used every week also made the topics of discussion varied. The students were free to comment on the questions given by the lecturer in the forum column. The discussion was one of the attendance aspects, so the students were obliged to discuss weekly. This made the students get used to being active and being able to develop their ability to express themselves orally in English.

Every week, there was an assignment in the form of a video that had to be uploaded to YouTube. Later, the links to the uploaded video were submitted through Be-Smart, both in the Word document and online text formats. Through this assignment, the students learned not only English but also how to talk in front of the camera with good performance and body gesture, how to edit video, being responsible for the video they made, how to design channel and thumbnail video, how to socialize and promote video and its channel in order to get many likes and subscribers, and how to build their self-confidence. Bakar, Latif, \& Ya'acob, (2017) and Misbah, Mohamad, Yunus, \& Ya'acob (2017) state that language development will be faster if the students are given the opportunity to learn and explore language without pressures from the teacher. In the teaching of English in this study, the students were given freedom to be creative in making English videos which were interesting and educative. Therefore, the students could develop their English competence in their own way by making videos (Combe \& Codreanu, 2016). The number of likes and 
subscribers functioned as the consideration in rating the students' work by the lecturer, so that the students became very enthusiastic and motivated to optimize their work in terms of both the video content and obtaining likes and subscribers. Hamat \& Hassan (2019) explain that social media can be used as a teaching aid in the teaching to develop writing, reading, and communication skills, and to develop vocabulary mastery. In this study, social media was certainly useful as the students' platform in promoting their YouTube channel. They practiced how to promote in an interesting way in order to attract many viewers. It was this assignment which was considered as the special feature of this subject. Every week, the students' social media was crowded because they promoted their videos.

In relation to the Covid-19 Pandemic, Almarzooq, Lopes, \& Kochar (2020) and Basilaia \& Kvavadze (2020) mention that there needs to be acceleration in the solution to educational problems. Teaching and learning must be managed and adapted to the situation and condition. Teaching and learning in all levels of education is designed to use online teaching and learning. In the English teaching in this study, the students had to study from home and lecture activities were done online in order to stop the spread of Covid-19. To anticipate this, the English teaching was conducted fully online, although there was face-toface interaction between the lecturer and students. Zoom application was used as the media to connect the lecturer and students to face each other in spite of the distance. Zoom is the application used in teleconference. This application enables many people to see each other at the same time. Maul, Berman, \& Ames (2018) mention that the use of Zoom application affects students psychologically, which contributes to the increase in their learning motivation.

As mentioned previously, the English teaching in this study applied the Communicative Approach. Two phenomena very frequently happened in the process. First, in the teaching-learning activities in the classroom the students could make grammatically accurate sentences but they could not use them in the communication outside the classroom. This was due to the fact that the situation in the classroom was illustrative - it was not the real situation which enabled them to use language directly. Second, the students understood the rules of language use, but they could not use the rules in real communication. For example, they knew how to apologize, to express opinions, and to offer something, but in real communication they could not do those communicative activities well. The two phenomena, which require that in real communication there needs not only linguistic competence but also communicative competence, underlie the shift in teaching approach from linguistic structure-centered approach to communicative approach (Larsen \& Freeman, 2008).

Brown (2007) defines communicative language teaching as the approach to language teaching which emphasizes authenticity, interaction, student-centered learning, task-based activities, communication for the real life, and meaningful purposes. The application of the Communicative Approach is a teacher's best choice to enable the students to develop their language skill, which is adapted to the situation and condition (Toro, Camacho-Minuche, Pinza-Tapia, \& Paredes, 2018). There are four purposes of communicative language teaching: to provide practices in comprehensive tasks, to enhance students' motivation, to provide natural learning, to create contexts that support (Littlewood, 1981). Scrivener (2005) mentions that teaching has to be aimed at giving opportunities to students to practice and analyze as well as to improve their language skill. It can be understood that communicative language teaching aims to develop the students' active English competence. Processing the competence or skills in English teaching and learning is very important. For this reason, the understanding of language competence in teaching and learning activities is needed.

According to Soenardi (2011) good language competencies are classified into four skills: listening skill, reading skill, speaking skill, and writing skill. Soenardi's opinion is supported by some experts and authorities who state that in order to know one's language competence, we need to look at his listening skill, reading skill, speaking skill, and writing skill. This is in line with Browne (2009) dan Tompkins \& Hoskisson (1995) who explain that the skills in using a language consist of four aspects: listening skill, reading skill, speaking skill, and writing skill. Therefore, English teaching should be designed to apply the Communicative Approach integrated with social media so as to accommodate all language skills to develop optimally.

The discussion activities in the Be-Smart forum, producing and uploading videos to YouTube, and question-and-answer activities in the classroom are the manifestation of the Communicative Approach in English language teaching. This approach makes the students communicate actively in English so that their understanding related to the English materials is not only to understanding the materials but also to their fluency in using the language. Shah \& Othman (2006) and Di Carlo (2015) state that the communicative approach or strategy teaches the students to learn a language contextually through everyday conversation naturally. Based on the result of the interview, the students find the English teaching a lot of fun. With the teaching which applied the Communicative Approach, the students felt that they were able build good communication with the lecturer and other fellow students. They were also 
more self-confident to express themselves in English. This is in line with the opinion of Akanbi \& Ndidi (2020) that the Communicative Approach can build students' self-confidence in learning, especially in developing their speaking skill.

The application of the communicative approach-based blended learning in the English teaching got positive responses from the students. The use of technology in teaching facilitated students to learn. They were enthusiastic about doing varieties of assignments such as making and uploading videos to YouTube. They felt that their creativity was channeled and that they could freely made innovation in the content of their quality educative videos (Courtois, Mechant, \& De Marez, 2012; DeWitt et al., 2013). Their perspectives in technology such as YouTube algorithm and video editing application also improved. Their skill in video editing and in designing YouTube channels and video thumbnail, which they did not get previously, became familiar to them. There were even many students who became interested in YouTube video content. The class situation which was so interactive and flexible made the students happy during the English teaching and learning process. That there was always something new in class made the students always interested in building communication and collaboration with the lecturer and other students.

In this study, the teaching of the English subject applying the blended learning method was in two different teaching processes: synchronous and asynchronous processes. The synchronous teaching (faceto-face) was conducted in the classroom when the lecturer and students met directly in person without any medium. The methods used in the synchronous teaching could be in the form of lecture, discussion, and question and answer. The synchronous teaching trained the students to develop their direct communication competence by expressing themselves during the teaching-learning processes (Tabak \& Rampal, 2014). Besides, the students could practice to socialize and communicate directly in English. They also had the opportunity to present the work they had prepared in front of the class. During the synchronous teaching the lecturer had the opportunity to measure his students' competence, such as listening comprehension. He administered an oral test in the classroom by playing audio materials through a loud speaker. Besides, the competence which could be measured in the synchronous teaching was writing comprehension. The lecturer played a video containing a short story, and then the students were asked to rewrite the story in their own words. The measurement of this competence is surely more effective during the synchronous teaching because the students are totally supervised by the lecturer in order that they try their best without cheating (Ramadhan, Chaeruman, \& Kustandi, 2018).

Another kind of interaction in blended learning in the English subject is asynchronous (long distant). The asynchronous teaching can use several online platforms to improve teaching efficiency and students' learning achievement (Sophocleous \& Loizides, 2016). The online platforms that could be used include Be-Smart, YouTube, and Zoom. In the asynchronous teaching, the students could develop their communication ability and express themselves in the written form. As one of the platforms that can be used in the asynchronous teaching, Be-Smart provides the room containing the materials which can be accessed by all students. This platform also provides a special column for the students to submit their assignments and to discuss in a forum. In the English teaching in this study, the students were asked to access materials, submit assignments, and discus in a forum in this platform weekly. Different materials used every week also made the topics of discussion varied. The students were free to comment on the questions given by the lecturer in the forum column. The discussion was one of the attendance aspects, so the students were obliged to discuss weekly. This made the students get used to being active and being able to develop their ability to express themselves orally in English.

Every week, there was an assignment in the form of a video that had to be uploaded to YouTube. Later, the links to the uploaded video were submitted through Be-Smart, both in the Word document and online text formats. Through this assignment, the students learned not only English but also how to talk in front of the camera with good performance and body gesture, how to edit video, being responsible for the video they made, how to design channel and thumbnail video, how to socialize and promote video and its channel in order to get many likes and subscribers, and how to build their self-confidence. Bakar, Latif, \& Ya'acob, (2017) and Misbah, Mohamad, Yunus, \& Ya'acob (2017) state that language development will be faster if the students are given the opportunity to learn and explore language without pressures from the teacher. In the teaching of English in this study, the students were given freedom to be creative in making English videos which were interesting and educative. Therefore, the students could develop their English competence in their own way by making videos (Combe \& Codreanu, 2016). The number of likes and subscribers functioned as the consideration in rating the students' work by the lecturer, so that the students became very enthusiastic and motivated to optimize their work in terms of both the video content and obtaining likes and subscribers. Hamat \& Hassan (2019) explain that social media can be used as a teaching aid in the teaching to develop writing, reading, and communication skills, and to develop vocabulary mastery. In this study, social media was certainly useful as the students' platform in 
promoting their YouTube channel. They practiced how to promote in an interesting way in order to attract many viewers. It was this assignment which was considered as the special feature of this subject. Every week, the students' social media was crowded because they promoted their videos.

In relation to the Covid-19 Pandemic, Almarzooq, Lopes, \& Kochar (2020) and Basilaia \& Kvavadze (2020) mention that there needs to be acceleration in the solution to educational problems. Teaching and learning must be managed and adapted to the situation and condition. Teaching and learning in all levels of education is designed to use online teaching and learning. In the English teaching in this study, the students had to study from home and lecture activities were done online in order to stop the spread of Covid-19. To anticipate this, the English teaching was conducted fully online, although there was face-toface interaction between the lecturer and students. Zoom application was used as the media to connect the lecturer and students to face each other in spite of the distance. Zoom is the application used in teleconference. This application enables many people to see each other at the same time. Maul, Berman, \& Ames (2018) mention that the use of Zoom application affects students psychologically, which contributes to the increase in their learning motivation.

As mentioned previously, the English teaching in this study applied the Communicative Approach. Two phenomena very frequently happened in the process. First, in the teaching-learning activities in the classroom the students could make grammatically accurate sentences but they could not use them in the communication outside the classroom. This was due to the fact that the situation in the classroom was illustrative - it was not the real situation which enabled them to use language directly. Second, the students understood the rules of language use, but they could not use the rules in real communication. For example, they knew how to apologize, to express opinions, and to offer something, but in real communication they could not do those communicative activities well. The two phenomena, which require that in real communication there needs not only linguistic competence but also communicative competence, underlie the shift in teaching approach from linguistic structure-centered approach to communicative approach (Larsen \& Freeman, 2008).

Brown (2007) defines communicative language teaching as the approach to language teaching which emphasizes authenticity, interaction, student-centered learning, task-based activities, communication for the real life, and meaningful purposes. The application of the Communicative Approach is a teacher's best choice to enable the students to develop their language skill, which is adapted to the situation and condition (Toro, Camacho-Minuche, Pinza-Tapia, \& Paredes, 2018). There are four purposes of communicative language teaching: to provide practices in comprehensive tasks, to enhance students' motivation, to provide natural learning, to create contexts that support (Littlewood, 1981). Scrivener (2005) mentions that teaching has to be aimed at giving opportunities to students to practice and analyze as well as to improve their language skill. It can be understood that communicative language teaching aims to develop the students' active English competence. Processing the competence or skills in English teaching and learning is very important. For this reason, the understanding of language competence in teaching and learning activities is needed.

According to Soenardi (2011) good language competencies are classified into four skills: listening skill, reading skill, speaking skill, and writing skill. Soenardi's opinion is supported by some experts and authorities who state that in order to know one's language competence, we need to look at his listening skill, reading skill, speaking skill, and writing skill. This is in line with Browne (2009) dan Tompkins \& Hoskisson (1995) who explain that the skills in using a language consist of four aspects: listening skill, reading skill, speaking skill, and writing skill. Therefore, English teaching should be designed to apply the Communicative Approach integrated with social media so as to accommodate all language skills to develop optimally.

The discussion activities in the Be-Smart forum, producing and uploading videos to YouTube, and question-and-answer activities in the classroom are the manifestation of the Communicative Approach in English language teaching. This approach makes the students communicate actively in English so that their understanding related to the English materials is not only to understanding the materials but also to their fluency in using the language. Shah \& Othman (2006) and Di Carlo (2015) state that the communicative approach or strategy teaches the students to learn a language contextually through everyday conversation naturally. Based on the result of the interview, the students find the English teaching a lot of fun. With the teaching which applied the Communicative Approach, the students felt that they were able build good communication with the lecturer and other fellow students. They were also more self-confident to express themselves in English. This is in line with the opinion of Akanbi \& Ndidi (2020) that the Communicative Approach can build students' self-confidence in learning, especially in developing their speaking skill.

The application of the communicative approach-based blended learning in the English teaching got positive responses from the students. The use of technology in teaching facilitated students to learn. They 
were enthusiastic about doing varieties of assignments such as making and uploading videos to YouTube. They felt that their creativity was channeled and that they could freely made innovation in the content of their quality educative videos (Courtois, Mechant, \& De Marez, 2012; DeWitt et al., 2013). Their perspectives in technology such as YouTube algorithm and video editing application also improved. Their skill in video editing and in designing YouTube channels and video thumbnail, which they did not get previously, became familiar to them. There were even many students who became interested in YouTube video content. The class situation which was so interactive and flexible made the students happy during the English teaching and learning process. That there was always something new in class made the students always interested in building communication and collaboration with the lecturer and other students.

\section{REFERENCES}

Abrejo, B., Sartaj, S., \& Memon, S. (2019). English language teaching through communicative approach: A qualitative study of public sector colleges of Hyderabad, Sindh. Advances in Language and Literary Studies, 10(5), 43. https://doi.org/10.7575/aiac.alls.v.10n.5p.43

Ahmadi, M. R. (2018). The use of technology in English language learning: a literature review. International Journal of Research in English Education (IJREE), 3(2), 115-125.

Akanbi, B. T., \& Ndidi, K.-O. C. (2020). Improving learners' oral proficiency in French through the Communicative Approach: colleges of education in Oyo in Focus. Journal of Curriculum and Teaching, 9(1), 55. https://doi.org/10.5430/jct.v9n1p55

Akkas, F. D., \& Coker, B. (2016). The use of communicative approach in 9th grade EFL classes. Eurasian Journal of Educational Research, 16(65), 1-35. https://doi.org/10.14689/ejer.2016.65.05

Almarzooq, Z. I., Lopes, M., \& Kochar, A. (2020). Virtual learning during the COVID-19 pandemic: A disruptive technology in graduate medical education. Journal of the American College of Cardiology, 75(20), 2635-2638. https://doi.org/10.1016/j.jacc.2020.04.015

Bakar, N. A., Latif, H., \& Ya'acob, A. (2017). Fusion of technology with language learning: Blog community. 3L: Language, Linguistics, Literature, 23(4), 200-211. https://doi.org/10.17576/3L-2017-2304-15

Basilaia, G., \& Kvavadze, D. (2020). Transition to online education in schools during a SARS-CoV-2 Coronavirus (COVID-19) pandemic in Georgia. Pedagogical Research, 5(4), 1-9. https://doi.org/10.29333/pr/7937

Brown, H. D. (2007). Teaching by Principle: An Interactive Approach to Language Pedagogy (3rd ed.). White Plains: Pearson Education.

Browne, A. (2009). Developing Language and Literacy 3 - 8 (3rd ed.). London: SAGE Publication Ltd.

Burke, S. C., Snyder, S., \& RC, R. (2009). An assessment of faculty usage of youtube as a teaching resource. The Internet Journal of Allied Health Sciences and Practice, 7(1), 1-8. https://doi.org/10.1353/cj.0.0098

Combe, C., \& Codreanu, T. (2016). Vlogging: a new channel for language learning and intercultural exchanges. CALL Communities and Culture - Short Papers from EUROCALL 2016, 2016(1), 119-124. https://doi.org/10.14705/rpnet.2016.eurocall2016.9781908416445

Courtois, C., Mechant, P., \& De Marez, L. (2012). Communicating creativity on youtube: What and for whom? Cyberpsychology, Behavior, and Social Networking, 15(3), 129-134. https://doi.org/10.1089/cyber.2011.0401

Devi, G. K., \& Rao, V. V. S. (2018). Integrated Approach - a Tool To Enhance English Speaking Skills. IManager's Journal on English Language Teaching, 8(3), 1. https://doi.org/10.26634/jelt.8.3.14565

DeWitt, D., Alias, N., Siraj, S., Yaakub, M. Y., Ayob, J., \& Ishak, R. (2013). The potential of youtube for teaching and learning in the performing arts. Procedia - Social and Behavioral Sciences, 103(2013), 1118-1126. https://doi.org/10.1016/j.sbspro.2013.10.439

Di Carlo, G. S. (2015). Pathos as a communicative strategy for online knowledge dissemination: The case of TED talks. 3L: Language, Linguistics, Literature, 21(1), 23-34. https://doi.org/10.17576/3l-20152101-03

Erarslan, A. (2019). Instagram as an education platform for EFL learners. Turkish Online Journal of Educational Technology - TOJET, 18(3), 54-69.

Fleck, B. K. B., Beckman, L. M., Sterns, J. L., \& Hussey, H. D. (2014). Youtube in the classroom: helpful tips and student perceptions. The Journal of Effective Teaching, 14(3), 21-37.

Grgurović, M. (2014). An application of the Diffusion of Innovations theory to the investigation of blended language learning. Innovation in Language Learning and Teaching, 8(2), 155-170. https://doi.org/10.1080/17501229.2013.789031

Hamad, M. M., Metwally, A. A., \& Alfaruque, S. Y. (2019). The impact of using youtubes and audio tracks 
imitation YATI on improving speaking skills of EFL learners. English Language Teaching, 12(6), 191. https://doi.org/10.5539/elt.v12n6p191

Hamat, A., \& Hassan, H. A. (2019). Use of social media for informal language learning by Malaysian University Students. 3L: Language, Linguistics, Literature, 25(4), 68-83. https://doi.org/10.17576/3L-2019-2504-05

Inal, M., \& Korkmaz, Ö. (2019). The effect of web based blended learning on students' academic achievement and attitudes towards English course. Education and Information Technologies, 24(4), 2603-2619. https://doi.org/10.1007/s10639-019-09890-7

Jabeen, S. S. (2014). Implementation of communicative approach. English Language Teaching, 7(8), 68-74. https://doi.org/10.5539/elt.v7n8p68

Kitchakarn, O. (2016). How students perceived social media as a learning tool in enhancing their language learning performance. Turkish Online Journal of Educational Technology, 15(4), 53-60.

Kocoglu, Z., Ozek, Y., \& Kesli, Y. (2011). Blended learning: Investigating its potential in an english language teacher training program. Australasian Journal of Educational Technology, 27(7), 1124-1134. https://doi.org/10.14742/ajet.908

Larsen, D., \& Freeman. (2008). Techniques and Principles in Language Learning (2nd Edition). Oxford: Oxford: Oxford University Press.

Li, V. (2017). Social media in english language teaching and learning. International Journal of Learning and Teaching, 3(2), 148-153. https://doi.org/10.18178/ijlt.3.2.148-153

Littlewood, W. (1981). Communicative Language Teaching. Cambridge: Cambridge University Press.

Lukyanova, N., Daneykin, Y., \& Daneikina, N. (2015). Communicative competence management approaches in higher education. Procedia - Social and Behavioral Sciences, 214(June), 565-570. https://doi.org/10.1016/j.sbspro.2015.11.761

Maul, J., Berman, R., \& Ames, C. (2018). Exploring the psychological benefits of using an emerging video technology to coach and retain doctoral learners. International Journal of Doctoral Studies, 13, 4978. https://doi.org/10.28945/3954

Megawati, F. (2016). Kesulitan students dalam mencapai pembelajaran bahasa Inggris secara efektif. Jurnal Pedagogia, 5(2), 147-156. https://doi.org/10.1007/s00381-016-3174-3

Miller, A. M., Morgan, W. J., \& Koronkiewicz, B. (2019). Like or tweet: analysis of the use of facebook and twitter in the language classroom. TechTrends, 63(5), 550-558. https://doi.org/10.1007/s11528018-0341-2

Misbah, N. H., Mohamad, M., Yunus, M. M., \& Ya'acob, A. (2017). Identifying the factors contributing to students' difficulties in the English language learning. Creative Education, 08(13), 1999-2008. https://doi.org/10.4236/ce.2017.813136

Moghavvemi, S., Sulaiman, A., Jaafar, N. I., \& Kasem, N. (2018). Social media as a complementary learning tool for teaching and learning: The case of youtube. International Journal of Management Education, 16(1), 37-42. https://doi.org/10.1016/j.ijme.2017.12.001

Ozmen, B., Tepe, T., \& Tuzun, H. (2018). Adapting a residential course to web-based blended learning. Egitim Arastirmalari - Eurasian Journal of Educational Research, 2018(75), 115-136. https://doi.org/10.14689/ejer.2018.75.7

Rahmawati, F. (2019). Blended learning in an English listening and speaking course: freshmen's voice and choice. Advances in Social Science, Education and Humanities Research, 353, 56-62. https://doi.org/10.2991/icosihess-19.2019.9

Ramadhan, R., Chaeruman, U. A., \& Kustandi, C. (2018). Pengembangan pembelajaran bauran (blended learning) di universitas negeri jakarta. Jurnal Pembelajaran Inovatif, 1(1), 37-48. https://doi.org/10.21009/JPI.011.07

Sari, A. R. (2013). Strategi blended learning untuk peningkatan kemandirian belajar dan kemampuan critical thinking students di era digital. Jurnal Pendidikan Akuntansi Indonesia, 11(2), 32-43. https://doi.org/10.21831/jpai.v11i2.1689

Scrivener, J. (2005). Learning Teaching: A Guide Book for English Language Teachers. Oxford, UK: Macmillan Education.

Shebansky, W. J. (2018). Blended learning adoption in an ESL context: obstacles and guidelines. TESL Canada Journal, 35(1), 52-77. https://doi.org/10.18806/tesl.v35i1.1284

Siew-Eng, L., \& Muuk, M. A. (2015). Blended learning in teaching secondary schools' English: a preparation for tertiary science education in Malaysia. Procedia - Social and Behavioral Sciences, 167, 293-300. https://doi.org/10.1016/j.sbspro.2014.12.677

Soenardi, D. (2011). Tes Bahasa Pegangan Bagi Pengajar Bahasa. Jakarta: PT Indeks.

Sophocleous, S. P., \& Loizides, F. (2016). Exploring the benefits and disadvantages of introducing synchronous to asynchronous online technologies to facilitate flexibility in learning. CALL 
Communities and Culture - Short Papers from EUROCALL 2016, (December), 363-368. https://doi.org/10.14705/rpnet.2016.eurocall2016.589

Tabak, F., \& Rampal, R. (2014). Synchronous e-learning: Reflections and design considerations. International Journal of Education and Development Using Information and Communication Technology, 10(4), 80-92.

Tavil, Z. M. (2010). Integrating listening and speaking skills to facilitate English language learner's communicative competence. Procedia - Social and Behavioral Sciences, 9. 765-770. https://doi.org/10.1016/j.sbspro.2010.12.231

Tompkins, G. E., \& Hoskisson, K. (1995). Language Arts: Content and Teachingg Strategies. New Jersy: Merrill.

Toro, V., Camacho-Minuche, G., Pinza-Tapia, E., \& Paredes, F. (2018). The use of the communicative language teaching approach to improve students' oral skills. English Language Teaching, 12(1), 110118. https://doi.org/10.5539/elt.v12n1p110

Tuncay, N., \& Uzunboylu, H. (2012). English language teachers' success in blended and online e-learning. Procedia - Social and Behavioral Sciences, 47(2012), 131-137. https://doi.org/10.1016/j.sbspro.2012.06.626

Woods, K., Gomez, M., \& Arnold, M. G. (2019). Using social media as a tool for learning in higher education. International Journal of Web-Based Learning and Teaching Technologies, 14(3), 1-14. https://doi.org/10.4018/ijwltt.2019070101

Yang, Y. I. J. (2014). The implementation of speaking fluency in communicative language teaching: An observation of adopting the 4/3/2 activity in high schools in China. International Journal of English Language Education, 2(1), 193. https://doi.org/10.5296/ijele.v2i1.5136 